\title{
REVIEW
}

\section{MONOCLONAL ANTIBODY DRUGS FOR SYSTEMIC LUPUS ERYTHEMATOSUS}

\author{
Zornitsa G. Kamenarska ${ }^{1}$, Maria H. Hristova ${ }^{2}$, Anton I. Vinkov ${ }^{3}$, Lyubomir A. Dourmishev ${ }^{4 *}$ \\ ${ }^{1}$ Molecular Medicine Center, Medical University, Sofia, Bulgaria, ${ }^{2}$ Department of Nephrology, Medical \\ University, Sofia, Bulgaria, ${ }^{3}$ Service de Neurologie, Hôpitaux Drome Nord, Romans-sur-Isère, France, \\ ${ }^{4}$ Department of Dermatology and Venereology, Medical University, Sofia, Bulgaria
}

\section{МОНОКЛОНАЛЬНЫЕ АНТИТЕЛА ПРИ ЛЕЧЕНИИ СИСТЕМНОЙ КРАСНОЙ ВОЛЧАНКИ}

Зорница Г. Каменарска ${ }^{1}$, Мария Хр. Христова ${ }^{2}$, Антон И. Винков ${ }^{3}$, Любомир А. Дурмишев ${ }^{4 *}$ ${ }^{1}$ Центр молекулярной медииины, Медицинский университет, София, Болгария, ${ }^{2}$ Кафедра нефрологии, Медицинский университет - София, Болгария, ${ }^{3}$ Отделение неврологии, Норрitaux Drome Nord, Romans-sur-Isère, Франция, ${ }^{4}$ Кафедра дерматологии и венерологии, Медицинский университет,

София, Болгария

\begin{abstract}
Systemic lupus erythematosus (SLE) is a heterogeneous autoimmune disease which engages most of the immune cells in its development. Various studies concerning the application of antibodies against TNF- $\alpha$, BlyS, CD20, CD22, IL-6R and complement factors in treatment of SLE have been recently conducted and in spite of the good results reported by some of them, no definite conclusion on their risk-benefit profile can be drawn. The current review summarizes the results obtained in the field and reveals the perspectives for the development of new and more effective strategies for SLE treatment in combination with other immunomodulating drugs.
\end{abstract}

Key words: systemic lupus erythematosus, anti-TNF- $\alpha$, anti-BlyS, anti-CD20, anti-CD22, anti-IL-6R, anticomplement antibodies

Folia Medica 2015; 57(2): 89-92

Copyright (C) 2015 Medical University, Plovdiv

\section{РЕЗЮМЕ}

Системная красная волчанка (СКВ) является гетерогенным аутоиммунным заболеванием, в патогенезе которого принимают участие разные иммунные механизмы. За последние годы накопилось достаточно большое количество данных о применении иммунных препаратов, содержащих антитела против TNF$\alpha$, BlyS, CD20, CD22, IL-6R и комплимента в лечении CKB, в которых независимо от сообщаемых хороших результатов отсутствуют категорические данные об их эффективности и безопасности. Данное обозрение стремится обобщить результаты в этой области и поискать перспективы новых, более эффективных терапевтических стратегий в лечении данного заболевания в комбинации с другими иммуномодулирующими препаратами.

Ключевые слова: системная красная волчанка, антитела против TNF- $\alpha$, BlyS, CD20, CD22, IL-6R u комплимента

\section{INTRODUCTION}

Systemic lupus erythematosus (SLE) is a heterogeneous autoimmune disease which involves most of the immune cells in its development. A variety of mechanisms implicated in its pathogenesis were established as apoptosis, formation of antibodies and immune response, which enables the creation of new therapeutic agents directed against specific targets. Recently, a number of studies on the application of different antibodies in the treatment of
SLE were conducted. In spite of the good results reported by some of them, no definite conclusion on their risk-benefit profile can be drawn. The current review summarizes the results obtained in the field until now.

\section{Anti-TNF-a}

TNF- $\alpha$ is a pleiotropic cytokine with both immunoregulatory and proinflammatory effects. It has been found to have higher levels in SLE patients

Article's history: Received: 27 March 2015; Received in a revised form: 20 May 2015; Accepted: 01 June 2015 *Correspondence and reprint request to: L. Dourmishev, Department of Dermatology and Venereology, Medical University, Sofia Tel: ++359 29230 438; E-mail: L_Dourmishev@mail.bg 
compared with the levels in healthy controls, which correlated with the disease activity. ${ }^{1}$ Adalimumab and infliximab, anti-TNF- $\alpha$ monoclonal antibodies used in the therapy of psoriasis or other inflammatory or autoimmune diseases, have been investigated in the therapy of SLE. In contrast, a case of subacute cutaneous lupus erythematosus occurring 2 to 3 weeks after subcutaneous administration of golimumab for rheumatoid arthritis was reported. ${ }^{2}$ Other researchers have reported that etanercept, anti-TNF- $\alpha$ fusion protein, is relatively safe and long-term effective for refractory lupus arthritis ${ }^{3}$. Recently an open-label study has demonstrated that anti-TNF therapy could suppress local tissue destruction in SLE, but at the same time, the use of anti-TNF- $\alpha$ agents leads to the formation of autoantibodies, including autoantibodies to the double-stranded DNA (ds-DNA). Cardiolipin levels were also found to be increased. ${ }^{4,5}$ A possible mechanism of the TNF blocker-induced lupus could be related to a shift from apoptosis to necrosis, which results in the release of nuclear debris that trigger the production of ANA. There is evidence indicating that patients treated with TNF blockers, especially those with positive ANA, should be closely monitored for developing SLE. ${ }^{6}$ Moreover, the induction of ANA or preexisting high-titer of ANA in TNF-treated patients is associated with the development of lupus and therefore TNF blockade is not advisable for this group of patients.

It is well known that all of the TNF- $\alpha$ inhibitors may induce lupus or lupus-like disease; however, the patient's risk level may differ from drug to drug. ${ }^{2,3}$ The reason could be the found in different apoptosis affection potential between the monoclonal antibodies and the fusion protein. ${ }^{7}$

\section{Anti-BlyS}

BlyS, also known as B cell activation factor, is a cytokine of the TNF ligand super-family that plays a key role in B lymphocyte differentiation, survival and activation. There is a defective regulation of BLyS in more than half of the SLE patients which is associated with higher BLyS serum levels that generally correlate with the anti-dsDNA concentration. ${ }^{8}$

Belimumab is a fully human monoclonal antibody that specifically recognizes and inhibits the biological activity of BLyS. The mechanisms of action are not entirely clear. Belimumab recognizes and binds to BLyS, inhibits the stimulation of $B$ cells, and restores the potential of the autoantibody-producing B cells to undergo the normal process of apoptosis. It reduces the number of the circulating B cells, but less deeply and durably than the anti-CD20 monoclonal antibodies. These characteristics of belimumab make it rationale for testing in patients with SLE.

\section{Anti-CD20}

The CD20 antigen is a membrane protein expressed on all mature B cells but not on plasma cells. Most lymphomas that develop in organ transplantation and in autoimmune diseases, including rheumatoid arthritis and SLE, are B-cell lymphomas.

Rituximab is very effective in depleting B cells from peripheral blood and moderately effective in clearing B cells from lymph nodes and bone marrow. The B cells depletion is rapid and may persist for 3 to 12 months. The Fab domain of rituximab binds to the CD20 antigen on B lymphocytes, and the $\mathrm{Fc}$ domain recruits immune effector functions to mediate B-cell lysis in vitro. A possible mechanism of cell lysis includes complement-dependent cytotoxicity, antibody-dependent-cell mediated cytotoxicity and stimulation of the apoptotic pathway. ${ }^{9}$ The effect of rituximab on the circulating levels of auto-antibodies, which are presumably secreted by the mature plasma cells unaffected by the antiCD20 antibody, is minor and rather inconsistent. Probably additional mechanisms of action operate, including memory cells depletion, abolition of antigen presentation by $\mathrm{B}$ cells and increased number of regulatory $\mathrm{T}$ cells. ${ }^{10}$

Although rituximab is nonspecific for lupus antibodies a number of uncontrolled studies reported its efficacy in some SLE patients, refractory to conventional treatments. ${ }^{11}$ The most common adverse effects are related to its first administration and consist in headache, nausea, urticaria and hyper- or hypotension. These reactions could be decreased by premedication with intravenous glucocorticoids. Rituximab is generally well tolerated when administrated alone or together with moderate doses of glucocorticoids or immunosuppressive agents, but it can render heavily immunosuppressed patients more susceptible to infection or severe neutropenia. However, the most serious complication is the progressive multifocal leukoencephalopathy probably caused by reactivation of the JC virus.

Veltuzumab and ocrelizumab, new anti-CD20 agents with modified structures are considered more effective than rituximab but the data are too limited. ${ }^{12}$

\section{Anti-CD22}

CD22 is a trans-membrane glycoprotein, which specifically binds sialic acid with an immunoglobulin 
domain located at its N-terminus. The presence of this domain makes CD22 member of the immunoglobulin super-family. CD22 functions as an inhibitory receptor for B-cell receptor signaling and regulates $\mathrm{B}$-cell migration and activity. There is a strict interaction between CD22 and CD19 - another regulator of $B$ cell receptor signals. CD22 inhibits the CD19 phosphorylation via the tyrosine-phosphatase SHP-1, while CD19 regulates the CD22 phosphorylation by augmenting the Lyn kinase activity. This CD19/CD22 loop was found significantly related to an autoimmune phenotype in mice ${ }^{13}$ and appeared to be a potential therapeutic target for modulating B cell signaling in SLE.

Epratuzumab is a recombinant, humanized monoclonal antibody directed against CD22, which is present on mature $\mathrm{B}$ cells and on many types of malignant B cells. After binding to CD22, epratuzumab exhibits predominantly an antitumor activity which is most probably mediated through antibody-dependent cellular cytotoxicity.

Upon administration, the skin lesions, arthralgias, and central nervous system manifestations rapidly improved while cardiac and renal manifestations improved less rapidly. No significant changes in $\mathrm{T}$ cells, immunoglobulins, or auto-antibody levels were observed. ${ }^{14}$ However, there was a pronounced reduction in CD27-B cells and CD22-surface-expression on $\mathrm{CD} 27-\mathrm{B}$ cells, suggesting that these cells, which mainly comprise naïve and transitional B cells, are preferentially targeted by epratuzumab in vivo. The results indicate additional regulatory effects of the antibody by reducing the enhanced activation and proliferation of anti-immunoglobulin-stimulated lupus B cells after co-incubation with CD40L or $\mathrm{CpG}$. Epratuzumab inhibited the proliferation of B cells from patients with SLE but not normal B cells under all culture conditions. ${ }^{15}$ It is likely that in contrast to CD20 antibodies, epratuzumab functions more by modulation of $\mathrm{B}$ cells rather than by their depletion. ${ }^{16}$ The encouraging initial findings and the good safety profile of epratuzumab make it promising for the treatment of SLE.

\section{Anti-COMPLEMENT ANTIBODIES}

Modulation of the complement system has been recognized as a promising strategy in drug discovery and a large number of therapeutic agents have been developed. There is evidence that the early complement proteins of the classic pathway $\mathrm{C} 1 \mathrm{q}$ and $\mathrm{C} 4$ are protective and their absence predisposes to SLE, whereas the activation of the terminal components of the complement i.e. C5b-C9 is pro-inflammatory and deleterious.

Eculizumab is a fully humanized monoclonal antibody directed against the complement protein C5. Its molecular weight is $148 \mathrm{kD}$. Eculizumab is approved for the treatment of paroxysmal nocturnal hemoglobinuria (PNH). The patients with that disease have a somatic genetic mutation in the $\mathrm{X}$-linked gene PIG-A. That leads to the absence of a complement regulatory protein and to a generation of abnormal red blood cells that are deficient in terminal complement inhibitors. By binding to $\mathrm{C} 5$, eculizumab inhibits its cleavage to $\mathrm{C} 5 \mathrm{a}$ and $\mathrm{C} 5 \mathrm{~b}$ and prevents the generation of the inflammatory terminal complement complex $\mathrm{C} 5 \mathrm{~b}-\mathrm{C} 9$ which exerts hemolytic activity. ${ }^{17}$

The mechanism of action of eculizumab makes it potentially attractive for the treatment of patients with lupus nephritis since the terminal components of the complement C5b-C9 play a role in inflammation and podocytes and glomerular basement membrane damage. The role of eculizumab in SLE is still being studied.

\section{Anti-IL-6R}

Tocilizumab is a humanized anti-IL-6R monoclonal antibody approved for the treatment of rheumatoid arthritis. The possibility to use it for the treatment of other inflammatory autoimmune diseases is still under investigation.

The blockade of the IL-6 receptor leads to a decrease in acute phase reactants and a decrease in immunoglobulin and anti-ds DNA antibodies, achieved probably by restoring the B-cells and Tcells homeostasis. Despite its efficacy, there were significant safety issues including bacterial keratitis and severe neutropenia which limits tocilizumab application in SLE. ${ }^{18}$

\section{Anti-IL-1 RECEPTOR ANTAGONIST}

Anakinra is a recombinant version of the human IL-1 receptor antagonist blocking the biological activity of IL-1. It is used for the treatment of severely active rheumatoid arthritis since it reduces arthritis, cartilage destruction, and bone resorption. IL-1 appeared involved in the etiology of glomerulonephritis in SLE which provides sufficient potential evidence to introduce anakinra for the treatment of SLE.

A number of antibodies such as anti-IL-18, antiIL-10 and anti-CD40L are also of interest but the data available are rather limited. ${ }^{19}$ 


\section{Anti-INFLAMMATORY PEPTIDES}

H2A histone fragment, termed IIIM1 and alpha1 -antitrypsin fragment (UBE) have been investigated on mice models of SLE. ${ }^{20}$ Both IIIM1 and UBE significantly reduce proteinuria, serum IL17, IL12 and anti dsDNA antibodies in animals, making them potential target of investigations in future.

\section{CONCLUSIONS}

The development of monoclonal antibodies directed against specific targets is a relatively new addition to the pharmacologic armamentarium available for the treatment of SLE. Despite the promising results no firm conclusion on their risk-benefit profile can be drawn from the available preliminary data. The results obtained showed that some of the antibodies could find application into the development of new and more effective strategies for SLE treatment after dose modification or in combination with other immunomodulating drugs.

\section{REFERENCES}

1. Aringer M, Feierl E, Steiner G, et al. Increased bioactive TNF in human systemic lupus erythematosus: associations with cell death. Lupus 2002;11(2):102-8.

2. Wilkerson E, Hazey MA, Bahrami S, et al. Golimumab-exacerbated subacute cutaneous lupus erythematosus. Arch Dermatol 2012;148(10):1186-90.

3. Cortés-Hernández J, Egri N, Vilardell-Tarrés M, Ordi-Ros J. Etanercept in refractory lupus arthritis: An observational study. Semin Arthritis Rheum 2015;44(6):672-9.

4. Aringer M, Graninger WB, Steiner G, et al. Safety and efficacy of tumor necrosis factor $\alpha$ blockade in systemic lupus erythematosus: an open-label study. Arthritis Rheum 2004;50(10):3161-9.

5. Aringer M, Smolen JS. Efficacy and safety of TNF blocker therapy in systemic lupus erythematosus. Expert Opin Drug Saf 2008;7(4):411-9.

6. Soforo E, Baumgartner M, Francis L, et al. Induction of systemic lupus erythematosus with tumor necrosis factor blockers. J Rheumatol 2010;37(1):204-5.

7. Moulis G, Sommet A, Lapeyre-Mestre M, et al. Is the risk of tumour necrosis factor inhibitor-induced lupus or lupus-like syndrome the same with monoclonal antibodies and soluble receptor? A case/non-case study in a nationwide pharmacovigilance database. Rheumatology (Oxford) 2014;53(10):1864-71.
8. Stohl W, Metyas S, Tan SM, et al. B lymphocyte stimulator overexpression in patients with systemic lupus erythematosus: longitudinal observations. Arthritis Rheum 2003;48(12):3475-86.

9. Smith MR. Rituximab (monoclonal anti-CD20 antibody): mechanisms of action and resistance. Oncogene 2003;22(47):7359-68.

10. Waldman M, Appel GB. Update on the treatment of lupus nephritis. Curr Opin Nephrol Hypertens 2013;22(2):224-30.

11. Sardesai VV, Sardesai VR, Agarwal TD. Steroidresistant autoimmune thrombocytopenia in systemic lupus erythematosus treated with rituximab. Indian J Dermatol 2015;60(1):106.

12. Faria RM, Isenberg DA. Three different B-cell depletion (anti-CD20 monoclonal antibodies) treatments for severe resistant systemic lupus erythematosus. Lupus 2010;19(10):1256-7.

13.Poe JC, Hasegawa M, Tedder TF. CD19, CD21, and CD22: multifaceted response regulators of $\mathrm{B}$ lymphocyte signal transduction. Int Rev Imunol 2001;20(6):739-62.

14.Dörner T, Kaufmann J, Wegener WA, et al. Initial clinical trial of epratuzumab (humanized anti-CD22 antibody) for immunotherapy of systemic lupus erythematosus. Arthritis Res Ther 2006;8(3):R74.

15. Jacobi AM, Goldenberg DM, Hiepe F, et al. Differential effects of epratuzumab on peripheral blood B cells of patients with systemic lupus erythematosus versus normal controls. Ann Rheum Dis 2008;67(4):450-7.

16. Goldenberg DM. Epratuzumab in the therapy of oncological and immunological diseases. Expert Rev Anticancer Ther 2006;6(10):1341-53.

17. Hillmen P, Young N, Schubert J, et al. The complement inhibitor eculizumab in paroxysmal nocturnal hemoglobinuria. N Engl J Med 2006;355(12):1233-43.

18. Illei GG, Shirota Y, Yarboro CH, et al. Tocilizumab in systemic lupus erythematosus: data on safety, preliminary efficacy, and impact on circulating plasma cells from an open-label phase I dosage-escalation study. Arthritis Rheum 2010;62(2):542-52.

19. Tocoian A, Buchan P, Kirby H, et al. First-in-human trial of the safety, pharmacokinetics and immunogenicity of a PEGylated anti-CD40L antibody fragment (CDP7657) in healthy individuals and patients with systemic lupus erythematosus. Lupus 2015;24(10):1045-56.

20. Shapira E, Proscura E, Brodsky B, et al. Novel peptides as potential treatment of systemic lupus erythematosus. Lupus. 2011;20(5):463-72. 